\title{
Customer Perception towards Electronic Banking and its Relationship with Customer Satisfaction: An Evidence from Vietnam
}

\author{
Linh Thi Phuong Nguyen ${ }^{1} \&$ Hieu Vo Chi Tran ${ }^{2}$ \\ ${ }^{1}$ Faculty of Business Administration, Asia-Pacific International University, Thailand \\ ${ }^{2}$ Faculty of Information and Technology, Asia-Pacific International University, Thailand \\ Correspondence: Nguyen Thi Phuong Linh, Faculty of Business Administration, Asia-Pacific International \\ University, 195 Moo 3 Muak Lek, Saraburi 18180, Thailand. Email: linh@apiu.edu
}

Received: June 2, 2020

doi:10.5539/ijbm.v15n7p196
Accepted: June 21, 2020

Online Published: June 23, 2020

\begin{abstract}
Electronic Banking (e-Banking) is a popular banking service all over the world nowadays because of its convenience and great benefits for both banks and customers. However, although e-Banking has been implemented in Vietnam for a long time, the awareness and usage of customers toward this banking service are still very low in reality. This study aims to provide an insight into customer perception of e-Banking and to figure out which areas of customer perception influence customer satisfaction of e-banking in Vietnam. A structured questionnaire was distributed to three hundred and fifty banking customers in Vietnam. The collected data were analyzed by using descriptive, Pearson's correlation, t-test, and ANOVA with Tukey analysis. The results illustrated customer perception of e-banking in Vietnam in different areas such as convenience, speed, security, procedure, ease of use, service costs, reliability, and quality of service. There were significant differences in customers' perception of electronic banking among ages, occupations, income levels, and frequency of using groups in Vietnam. However, variables such as gender, marital status, and education levels had no significant influence on the perceptions of electronic banking. The study also found that except service costs, other factors such as convenience, speed, security, ease of use, reliability, quality of service, and procedure are positively related to customer satisfaction of electronic banking in Vietnam. Thus, it implies that bank managers should focus on these areas to raise customer perception and customer satisfaction of electronic banking.
\end{abstract}

Keywords: electronic banking, customer perception, customer satisfaction

\section{Introduction}

E-Banking is the banking service using electronic means such as a personal computer (PC), automated teller machine (ATM), mobile phone, etc. to conduct transactions via the Internet. This term is more and more popular for banking users and represents the modern method of banking that replaces gradually traditional one using cash for transactions.

Along with the boom of the Internet, nowadays, e-Banking is developing rapidly all over the world. It becomes an inevitable trend and an indispensable tool for any bank which wants to enrich its services as well as reach more customers. E-Banking brings a lot of benefits to banks as well as customers. For banks, e-Banking helps them be more competitive with multiple transaction channels, and also reduce overhead and operating costs. For customers, they can get the many benefits from the convenience of e-Banking such as accessing bank services anywhere and anytime, quick and simple transactions, reducing risks about security with cash on hand, etc. Moreover, customers can check records of transactions so that they have an overview of their finances.

However, until now, e-Banking is still an infancy stage in Vietnam although domestic and international banks have implemented e-Banking for a long time. According to "Personal Finance Monitor" report in Vietnam (2010) of Nielsen Company, although $24 \%$ of population access Internet - the second highest in Asia, $52 \%$ of customers have awareness about Internet Banking (i-Banking) - a type of e-Banking, only by around 1\% of customers actually use in reality. There were 54.7 million internet users in Vietnam in 2018 and this figure is projected to grow to 75.7 million internet users in 2022 (Doan, 2019). Except for ATM, other types of e-Banking such as mobile-Banking (m-Banking) or credit cards also have low awareness and usage in Vietnam. The problems with 
e-Banking in Vietnam may come from the lack of investment, less experience of operating and implementation, or poor marketing of banks; or from the habit in using cash, lack of information, or overlooking the benefits of e-Banking of Vietnamese customers. According to the "Vietnam Mobile App Market Report", though electronic banking penetrated $81 \%$ of existing banking users, most of the customers still preferred "Cash-on-Delivery" method and it is accounted for $88 \%$ of total e-commerce payments (Appota, 2018). As e-commerce is booming and there are growing opportunities for electronic banking, there is no research has been done so far to identify problems and what customers feel about the current e-Banking service in Vietnam.

Therefore, the main purpose of this research is to find out customer perception of the current e-Banking service in Vietnam and whether demographics influence customer perception of e-Banking. In addition, this research paper also investigates if there is any relationship between customer perceptions in terms of convenience, speed, security, procedure, ease of use, service cost, reliability, quality of service, and customer satisfaction.

\section{Literature Review and Hypotheses Development}

In the contemporary digital age, e-Banking with various types is replacing traditional banking gradually and also becoming a power tool pushing the development of electronic commerce. According to Gonzalez, Mueller, \& Mack (2008), e-Banking has grown rapidly and transformed traditional practices in banking. And a dominant part of the future of banking business lies in e-Banking which allows customers to access banking services remotely (Srivastava, 2007). Both banks and customers get huge benefits from e-Banking. It increases the efficiency of the banking operation along with providing more convenience to customers (Singhal \& Padhmanabhanm, 2008). Through e-Banking, banks try to extend their services and utilities in order to attract more customers and satisfy them. But e-Banking may fail if it cannot meet the needs or expectations of customers. They just get satisfied with e-Banking when it provides maximum convenience and comfort while transacting with the bank (Singhal \& Padhmanabhanm, 2008).

The main difference of e-Banking from traditional banking is the focus on providing convenience to customers. Williamson (2006) stated that "it provides customers convenience and flexibility and can be provided at a lower cost than traditional branch banking" (p. 1). By its several and various types and the support of modern technology, e-Banking can help customers access banking services anytime and anywhere, and make transactions in a simpler and faster way. According to Gbadeyan \& Akinyosoye-Gbonda (2011), the various e-Banking services and products provide customers with new ways of convenience rather than conventional banking. Hence, the diversity of types of e-Banking services is the key that helps banks reach more types of customers. Besides that, the advantage of e-Banking is the ease of tracking. All transactions done by e-Banking are recorded, and customers can track them easily. Thus, they can control their finances more effectively.

However, all benefits and advantages of e-Banking will become useless if just a few customers know about them. A good e-Banking system with various types of service may fail at the first stage if it cannot catch the awareness of customers. According to Mansor, Shariff, \& Manap (2012), "the exploration and understanding of awareness are always critical to ensure that organization or banking sector can remain successful and competitive in the industry" (p. 96). In reality in Vietnam, e-Banking is still very new with limited services although some e-Banking services have implemented for a long time. Banks in Vietnam seem to underestimate the benefit and importance of e-Banking. Excluding ATM, other types of e-Banking are not invested and marketed widely and seriously. Moreover, most Vietnamese people prefer to keep cash and implement transactions by cash as a habit, so they often overlook e-Banking services. The less effort from banks and also customers may lead to a lower awareness of e-Banking.

E-Banking is the new banking method that applies many modern technologies such as the Internet and mobile phone. There may be a relationship between the age of customers and the adoption of new technology. Older customers often adopt and catch the pace of development of technology harder and slower than younger. Fonchamnyo (2013) stated that "older customers are found to have a negative attitude towards technology and innovation as compared to younger adults who are more interested in using these new technologies. Thus, older customers are less likely to adopt e-banking" (p. 169, 170). Moreover, e-Banking relies much on the Internet. A lot of e-Banking services require the Internet to implement transactions. That means customers need a certain level of Internet literacy to approach e-Banking services such as i-Banking. According to Burke (2002), higher education customers are more comfortable with new technology such as the Internet. Besides that, the result of the study on the adoption of Internet service of Black, Lockett, Winklhofer, \& Ennew (2001) showed that people with high income and great use of information technology were likely to purchase financial services using Internet channels. So, they could have different perceptions and use more often e-Banking services than people with lower education. 
Besides new technology adoption, another issue that may become a barrier to e-Banking is the trust of customers toward it. According to Srivastava (2007), "there are various psychological and behavioral issues such as trust, the security of Internet transactions, reluctance to change and preference for the human interface which appear to impede the growth of Internet banking" (p. 68). Another similar idea from Hassan (2012), "trust is the vital issue regarding the use of e-banking for both of the parties (bank \& customers) who are not having face-to-face communication as well as there is also uncertainty in the user's mind about the security of online transaction" ( $p$. 87). Internet is the base of e-Banking, but it is also a prosperous land for hackers to exploit. The reality shows that there is not $100 \%$ guaranty for online transactions. They contain hidden risks such as leaking and loss of control the private data for both banks and customers. Those risks may from the carelessness of customers or the underestimate security issues of banks. To bring trust to the customers in using e-Bank, the banks need to have a sufficient and serious perception about security to protect privacy data of customers and prevent illegal access. Hence, "authenticating customers logging onto their online banking service has become a crucial concern of financial institutions" (p. 1) (Williamson, 2006). They "must be able to strengthen user authentication in the online environment to protect their customers and maintain confidence" (p. 2) (Williamson, 2006). However, "they must also ensure that stronger authentication does not negatively impact users' online banking experience" (p. 2) (Williamson, 2006).

If the security is the submerged part of the iceberg that sometimes customers overlook, the ease of use is the floating part that customers always concern about it. When they experience a hard time using services, they may feel uncomfortable and drop those unpleasant services. And e-Banking is not an exception. Nowadays, banks try to integrate many utilities in one to help customers experience convenience. For example, through ATM, customers can withdraw or transfer money or use electronic payment services, and they can even use more utilities through i-Banking such as controlling finances and doing investment. However, bad and clumsy design in the user interface of e-Banking services may confuse and irritate customers. According to Hernández-Ortega, Jiménez-Martínez, \& Hoyos (2007), the poor design of a website often leads to failures in online banking. And Cooper (1997) also stated that the design of the web-sites with appropriate use of a graphical user interface was also considered as an important determinant. A navigable website allows users to find the information easily and carry out their operations quickly (Hernandez-Orteg, Jimenez-Martinez, \& Hoyos, 2007).

Another important issue that affects customer perception of e-Banking is the quality and performance of service. Although banks succeed in building friendly and easy-to-use e-Banking services, if the quality of those services is low or their performance is not stable, the reliability from customers will drop down quickly. Because of the obvious relationship with customer satisfaction and retention, service quality has received much attention (Al-Hawari, Harley, \& Ward, 2005). According to Santos (2003), service quality is one of the main factors determining the success and failure of electronic commerce that e-Banking is a part of. Along with the human factor, technology is very important for e-Banking to improve and maintain the quality of services. Any technical problems that happen can strongly affect the quality of e-Banking. If banks invest in technology sufficiently and appropriately, they will have a strong base or infrastructure to provide high quality e-Banking services with strong security. According to Sriyastava (2007), "information technology has introduced new business paradigms and is increasingly playing a significant role in improving the services in the banking industry" (p. 68).

For banks, the ultimate goal of implementing e-Banking is to reach more customers or to get more market share. But they may create barriers by themselves that prevent customers approach e-Banking. They may be complicated procedures, inflexible regulations, or high service costs. Those barriers discourage customers to adopt e-Banking.

Hypothesis 1: There is a significant difference in customer perception of e-banking among demographic characteristics such as gender, marital status, age, education, occupation, income level, and frequency of use.

- H1a: There is a significant difference in customer perception of e-banking among gender groups.

- H1b: There is a significant difference in customer perception of e-banking among marital status groups.

- H1c: There is a significant difference in customer perception of e-banking among age groups.

- H1d: There is a significant difference in customer perception of e-banking among education level groups.

- H1e: There is a significant difference in customer perception of e-banking among occupation groups.

- H1f: There is a significant difference in customer perception of e-banking among income level groups.

- H1g: There is a significant difference in customer perception of e-banking among frequency of use groups.

Hypothesis 2: There is a significant relationship between customer perception of e-Banking in terms of 
convenience, speed, security, procedure, ease of use, service cost, quality of service, and reliability, and customer satisfaction.

\section{Significance of This Research}

E-Banking is now very popular and developing very fast all over the world. However, the pace of development of e-Banking is still very slow, and the interest of customers in e-Banking is also low in Vietnam. This situation has been maintained for recent years and no study that has figured out the problems. Hence, it is necessary to have a study to find out the overview of customer perception toward the current status e-Banking, and also barriers between them. From the results of this study, banks can reevaluate their e-Banking services based on understanding what customers perceive toward those services. So they can create good plans and strategies to improve and develop e-Banking to a new high level.

\section{Data and Methodology}

\subsection{Population and Sampling Design}

The objects of this study are all customers of domestic and foreign banks in Vietnam. When conducting this research, the researchers have limited time and budget to access the whole population of the research. Consequently, for accomplishing the research, the researchers select a sample for representing the whole population. The size of the sample is 350 people.

\subsection{Data Collection}

A quantitative method was used to collect data. Customers of banks in Vietnam were given a questionnaire to complete. Questionnaires were distributed to customers when they come to the banks for using services from January 10 to May 31, 2018 in Ho Chi Minh, Da Nang Can Tho, and Hanoi. The researchers used convenient sampling in selecting customers to distribute questionnaires of this study.

\subsection{Data Analysis}

The research used 350 questionnaires to analyze information for the result of this study. Statistical analysis was used to analyze collected data from the survey questionnaire. Answers to these surveys were converted into numbers to analyze. The information helps to decide whether we should accept or reject the hypotheses stated at the beginning of the study. Data were put into the SPSS program. Statistical tools for data analysis that will be used for this study are:

- Descriptive Statistics: are used to describe the basic features of customers of Vietnamese banks in this study.

- Pearson's Correlation: is a technique for examining the relationship between two variables and also the strength of the relationships.

- T-test: assesses whether the means of two groups are statistically different from each other.

- ANOVA analysis: is a statistical technique used to test a hypothesis concerning the means of three or more groups.

\section{Results and Findings}

\subsection{Descriptive Statistics}

The results show that there were $204(58.3 \%)$ of females and $146(41.7 \%)$ of males who participated in this study. Most of the participants were single $(53.7 \%)$ and $46.3 \%$ of them were married. More than half $(53.4 \%)$ of them were between 20 to 29 years old. There were $29.1 \%$ of the respondents who were between 30 to 39 years old, $10 \%$ of them were from 40 to 49 years old, only $4 \%$ of them were above 49 years old and $3.4 \%$ of them were below 20 years old.

Most of the participants of this study had higher education of studies. Three fourth of the respondents $(75.4 \%)$ had a bachelor's degree or diploma. While there are $13.1 \%$ of them got a master degree or a doctoral degree of education, only a few participants (10\%) were still studying in high school and $1.4 \%$ of them had less than high school education. The distribution of the survey showed different types of occupations. The largest occupation was "government employee" (21.1\%) and "company's employee" (21.1\%). The second highest (17.7\%) was "students". While there were $14 \%$ of them who were housewives or husbands, about $13.7 \%$ responded to "other occupations" and $12.3 \%$ of them were self-employed. For the level of income, most of the participants $(42.6 \%)$ had income between 5 to 10 million VND. There were $34.9 \%$ of them who had less than 5 million VND of monthly income. $12.3 \%$ of the respondents earned income between 10 to 15 million VND. While $2.9 \%$ of them got income between 20-25 million VND and only 2.3\% had income more than 25 million VND. From the survey, 
almost half of the participants (42.3\%) used electronic banking services at least once a month. There were $26.6 \%$ of them who used banking services at least once a week or more than once a week, and only $4.6 \%$ of the respondents never used any banking services.

\subsection{Analysis of Customers' Perceptions of Electronic Banking in Vietnam}

Table 1. Customers' perceptions of electronic banking in Vietnam

\begin{tabular}{|c|c|c|c|c|c|}
\hline & Mean & $\begin{array}{l}\text { Standard } \\
\text { Deviation }\end{array}$ & $\begin{array}{r}\text { Percent } \\
\text { Agreed }\end{array}$ & $\begin{array}{c}\text { Percent } \\
\text { Disagreed }\end{array}$ & $\begin{array}{c}\text { No } \\
\text { Opinion } \\
\end{array}$ \\
\hline \multicolumn{6}{|l|}{ Convenience } \\
\hline 1. It is easy to access to banking services anywhere. & 3.95 & 0.82 & 70.86 & 2.86 & 26.29 \\
\hline $\begin{array}{l}\text { 2. It is difficult to transfer money by ATM to any other bank } \\
\text { accounts. }\end{array}$ & 2.73 & 0.97 & 19.14 & 45.43 & 35.43 \\
\hline $\begin{array}{l}\text { 3. There are many types of e-Banking services for customers to } \\
\text { select. }\end{array}$ & 3.97 & 0.79 & 78.00 & 4.00 & 18.00 \\
\hline \multicolumn{6}{|l|}{ Speed } \\
\hline 4. The speed of ATM is fast. & 3.81 & 0.85 & 64.00 & 4.29 & 31.71 \\
\hline $\begin{array}{l}\text { 5. The processing time of payments through internet banking is } \\
\text { slow. }\end{array}$ & 2.61 & 0.86 & 13.71 & 48.57 & 37.71 \\
\hline $\begin{array}{l}\text { 6. The processing time of payments through mobile banking is } \\
\text { fast. }\end{array}$ & 3.59 & 0.98 & 55.14 & 15.14 & 29.71 \\
\hline \multicolumn{6}{|l|}{ Security } \\
\hline 7. It is secure to pay money through e-Banking services. & 3.52 & 0.83 & 49.71 & 7.71 & 42.57 \\
\hline 8. It is dangerous to withdraw money at the ATM booth. & 3.47 & 0.85 & 47.43 & 10.57 & 42.00 \\
\hline $\begin{array}{l}\text { 9. Private information is protected when using e-Banking } \\
\text { services. }\end{array}$ & 3.71 & 0.83 & 62.86 & 7.14 & 30.00 \\
\hline \multicolumn{6}{|l|}{ Procedure } \\
\hline $\begin{array}{l}\text { 10. The procedure of applying for e-Banking services is } \\
\text { complicated. }\end{array}$ & 3.11 & 0.97 & 34.57 & 27.71 & 37.71 \\
\hline 11. It takes a long time for applying for e-Banking services. & 2.90 & 0.89 & 21.14 & 31.14 & 47.71 \\
\hline $\begin{array}{l}\text { 12. The procedure to complete an electronic transaction is } \\
\text { simple. }\end{array}$ & 3.52 & 0.83 & 50.29 & 7.43 & 42.29 \\
\hline 13. The procedure to deal with complaint is complicated. & 3.40 & 0.95 & 43.14 & 15.71 & 41.14 \\
\hline \multicolumn{6}{|l|}{ Ease of use } \\
\hline 14. It is difficult to use internet banking service. & 2.48 & 0.83 & 11.14 & 57.14 & 31.71 \\
\hline 15. Design of website is friendly for using. & 3.52 & 0.92 & 58.57 & 16.86 & 24.57 \\
\hline $\begin{array}{l}\text { 16. There are instruction manuals available for using e-Banking } \\
\text { services. }\end{array}$ & 3.64 & 0.87 & 55.71 & 8.00 & 36.29 \\
\hline \multicolumn{6}{|l|}{ Service costs } \\
\hline 17. Annual fee of banking cards is very high. & 3.32 & 0.94 & 41.14 & 16.57 & 42.29 \\
\hline $\begin{array}{l}\text { 18. Transaction fee is lower with e-Banking services than } \\
\text { conventional banking. }\end{array}$ & 3.16 & 0.96 & 40.29 & 22.29 & 37.43 \\
\hline 19. Service fee is high with e-Banking. & 3.16 & 0.95 & 39.43 & 21.14 & 39.43 \\
\hline \multicolumn{6}{|l|}{ Reliability } \\
\hline 20. E-banking records of transactions are reliable. & 3.92 & 0.80 & 73.71 & 3.71 & 22.57 \\
\hline 21. Transactions of internet banking are trust worthy. & 3.53 & 0.80 & 54.29 & 9.14 & 36.57 \\
\hline \multicolumn{6}{|l|}{ Quality of Services } \\
\hline 22. Quality of internet banking service is bad. & 2.69 & 0.83 & 14.00 & 43.43 & 42.57 \\
\hline 23. There are a lot of problems when using ATM. & 3.29 & 0.91 & 39.71 & 17.71 & 42.57 \\
\hline 24. Mobile banking transactions are convenient. & 3.65 & 0.82 & 59.43 & 6.57 & 34.00 \\
\hline $\begin{array}{l}\text { 25. Banks reimburse the money quickly for customers when } \\
\text { personal information is lost due to security fault of the banks. }\end{array}$ & 3.12 & 0.98 & 35.14 & 24.29 & 40.57 \\
\hline
\end{tabular}

From Table 1, the results showed that the majority of the participants (70.86\%) agreed that it was easy to access banking services anywhere. Besides, there were many participants (45.43\%) who disagreed that it was difficult 
to transfer money by ATM to any other bank accounts while $35.43 \%$ of the participants were neutral. Most of the participants $(78 \%)$ responded that there were many types of e-Banking services for them to select.

In the perception of speed, as many as $64 \%$ of respondents expressed that the speed of the ATM was fast and only $4.29 \%$ of customers felt that the ATM was not fast enough for them to withdraw money or use the services that the ATM provided. Many participants $(48.57 \%)$ indicated that the processing time of payments through internet banking was fast while a few participants $(13.71 \%)$ indicated that it took a longer time to pay money through the internet. Nevertheless, more than half of the participants (55.14\%) agreed that the processing time of payments through mobile banking was short.

In term of security, almost $50 \%$ of the participants ensured that it was secure to pay money through e-Banking services. However, there are $47.43 \%$ of participants viewed that it was dangerous to withdraw money at the ATM booth. In contrast, many participants $(62.86 \%)$ believed that private information was protected when using e-Banking services.

About the procedure of applying for electronic banking, over 30\% of customers indicated that the procedure was complicated while $27.71 \%$ felt that it was simple. From the results in Table 1, close to half of the participants $(47.71 \%)$ were unsure about the length of time for applying for e-Banking services. On the other hand, about $31.14 \%$ of the respondents said that they could apply e-banking services in a short time. In addition, half of the customers (50.29\%) expressed that the procedure to complete an electronic transaction was simple while $42.29 \%$ of them had no opinion. When it comes to the procedure to deal with complaints, about $43.14 \%$ of customers consented that the procedures were complicated while $41.14 \%$ of the respondents had no opinion.

In the perception of ease of use, a large percentage of the participants (57.14\%) disagreed that it was difficult to use internet banking services. There are almost $60 \%$ of the participants liked the design of the website of internet banking which was friendly to use. About $55.71 \%$ of the respondents agreed that there were instruction manuals available for using e-Banking services. Meanwhile, there are $36.29 \%$ of them answered they had no opinion about the availability of instruction manuals for e-Banking services.

According to the results, most of the participants $(42.29 \%)$ were unsure if the annual fee of banking cards was high or low. It is interesting that $41.14 \%$ of the participants responded that the annual fee of banking cards was very high. In addition, many customers $(40.29 \%)$ responded that the transaction fee was lower with e-Banking services than conventional banking. Almost $40 \%$ of them were not aware of the transaction fee of electronic banking. Surprisingly, the number of participants who said the service fee of e-Banking was high was equal to the number of people $(39.43 \%)$ who had no opinion about it.

Regarding the reliability of the service, over $70 \%$ of the participants indicated that e-Banking transactions were reliable. Furthermore, the majority of participants $(54.29 \%)$ felt that transactions of internet banking were trustworthy, and only $9.14 \%$ of the participants disagreed with it.

Additionally, most of the customers indicated that the quality of internet banking service is good because the majority (43.43\%) answered disagree with the negative statement. Yet, $42.57 \%$ of the participants responded neutrally. There were about $40 \%$ of customers faced a lot of problems when using ATM service. Almost $60 \%$ of respondents thought that mobile banking transactions were convenient. The majority of the participants $(40.57 \%)$ had no opinion if the bank would reimburse the money quickly to them when personal information was lost due to the security fault of the banks. Meanwhile, 35.14\% of them believe that the bank would reimburse the money as fast as possible to their customers when they had faults in their security systems.

\subsection{Analysis of Customer Satisfaction of Electronic Banking in Vietnam}

Table 2. Customer satisfaction of electronic banking in Vietnam

\begin{tabular}{lccccc}
\hline & Mean & Standard Deviation & Percent Agreed & Percent Disagreed & No opinion \\
\hline 1. I'm satisfied when using ATM service. & 3.52 & 0.93 & 58.00 & 16.29 & 25.71 \\
2. I'm satisfied when using Internet banking. & 3.65 & 0.71 & 60.86 & 5.14 & 34.00 \\
3. I'm satisfied when using Mobile banking. & 3.38 & 0.83 & 39.43 & 11.71 & 48.86 \\
4. I'm satisfied when using Debit/Credit Card. & 3.20 & 0.82 & 31.71 & 15.71 & 52.57 \\
\hline
\end{tabular}

According to the results of Table 2, almost $60 \%$ of the participants responded they were satisfied when using ATM service. The majority of the participants $(60.86 \%)$ were also pleased with internet banking. Almost half of the participants $(48.86 \%)$ had no opinion about their satisfaction in using mobile banking. On the other hand, 
there were $39.43 \%$ of them who were satisfied with mobile banking. More than half of the respondents $(52.57 \%)$ are undecided whether they were contented to use debit or credit cards or not, while $31.71 \%$ of them felt satisfied when using debit or credit cards.

\subsection{T-test and ANOVA Analysis}

Table 3. T-test result comparing Males and Females in customer perception of electronic banking in Vietnam

\begin{tabular}{|c|c|c|c|c|c|c|c|c|}
\hline Variable & Male & & Female & & & & & \\
\hline \multirow{2}{*}{ Perception Average } & M & SD & M & $\mathrm{SD}$ & $\mathrm{t}$ & $\mathrm{p}$ & $95 \% \mathrm{Cl}$ & Mean Difference (d) \\
\hline & 3.3501 & .34494 & 3.3118 & .33468 & 1.044 & .297 & {$[-.0339, .11065]$} & .03837 \\
\hline
\end{tabular}

An independent sample t-test showed that the difference between the Male group $(\mathrm{n}=146, \mathrm{M}=3.35, \mathrm{SD}=0.34)$ and the Female group $(\mathrm{n}=204, \mathrm{M}=3.31, \mathrm{SD}=0.33)$ were not statistically significant, $\mathrm{t}(350)=1.044, \mathrm{p}=.922$, $95 \%$ CI $[-.0339, .11065], \mathrm{d}=0.038$. So, hypothesis H1a is rejected. There is no statistically significant difference in customer perception of e-banking between males and females.

Table 4. T-test result comparing marital status in customer perception of electronic banking in Vietnam

\begin{tabular}{|c|c|c|c|c|c|c|c|c|}
\hline Variable & Single & & Married & & & & & \\
\hline \multirow{2}{*}{ Perception Average } & M & SD & M & SD & $\mathrm{t}$ & $\mathrm{p}$ & $95 \% \mathrm{Cl}$ & Mean Difference (d) \\
\hline & 3.3175 & .33861 & 3.3366 & .34006 & -.524 & .601 & {$[-.09062, .05249]$} & -0.01906 \\
\hline
\end{tabular}

An independent sample t-test showed that the difference between the Single group $(\mathrm{n}=162, \mathrm{M}=3.32, \mathrm{SD}=$ $0.34)$ and the Married group $(\mathrm{n}=188, \mathrm{M}=3.34, \mathrm{SD}=0.34)$ were not statistically significant, $\mathrm{t}(350)=-0.524, \mathrm{p}$ $=.601,95 \%$ CI [-.09062, .05249], $\mathrm{d}=-0.019$. So, hypothesis H1b is rejected. There is no statistically difference in customer perception of e-banking between single and married groups. 
Table 5. ANOVA results between age, education levels, occupations, income levels and frequency of use and customers' perception of electronic banking

\begin{tabular}{|c|c|c|c|c|c|}
\hline Item & $\mathrm{N}$ & Mean & $\mathrm{F}$ & Significant Level & Conclusion \\
\hline \multicolumn{6}{|l|}{ Ages } \\
\hline Less than 20 & 12 & 3.3500 & 3.28 & $0.012 * *$ & H1c: Accepted \\
\hline $20-29$ & 187 & 3.2710 & & & \\
\hline $30-39$ & 102 & 3.3957 & & & \\
\hline $40-49$ & 35 & 3.3623 & & & \\
\hline More than 49 & 14 & 3.4857 & & & \\
\hline \multicolumn{6}{|l|}{ Education Levels } \\
\hline Less than High School & 5 & 3.0720 & 1.143 & .332 & H1d: Rejected \\
\hline High School & 35 & 3.3211 & & & \\
\hline Bachelor Degree or Diploma & 264 & 3.3383 & & & \\
\hline Master Degree of Doctorate Degree & 46 & 3.3000 & & & \\
\hline Less than High School & 5 & 3.0720 & & & \\
\hline \multicolumn{6}{|l|}{ Occupations } \\
\hline Student & 62 & 3.2968 & 4.594 & $.000^{*}$ & H1e: Accepted \\
\hline Government Employee & 74 & 3.3778 & & & \\
\hline Company's employee & 74 & 3.2968 & & & \\
\hline Housewife/husband & 49 & 3.1616 & & & \\
\hline Self-employed & 43 & 3.4074 & & & \\
\hline Others & 48 & 3.4367 & & & \\
\hline \multicolumn{6}{|l|}{ Income Levels } \\
\hline Less than 5 million VND & 122 & 3.1974 & 6.438 & $.000 *$ & H1f: Accepted \\
\hline 5 million - 10 million VND & 149 & 3.3936 & & & \\
\hline 10 million - 15 million VND & 43 & 3.3916 & & & \\
\hline 15 million - 20 million VND & 18 & 3.4111 & & & \\
\hline 20 million - 25 million VND & 10 & 3.3320 & & & \\
\hline More than 25 million VND & 8 & 3.5550 & & & \\
\hline \multicolumn{6}{|l|}{ Frequency of use } \\
\hline Never & 16 & 3.2400 & 10.885 & $.000^{*}$ & H1g: Accepted \\
\hline Once a month & 148 & 3.2303 & & & \\
\hline Once a week & 93 & 3.3570 & & & \\
\hline More than once a week & 93 & 3.4688 & & & \\
\hline
\end{tabular}

The one-way ANOVA compared the means between the age groups, education levels, occupation groups, income levels and frequency of use and determined whether those means were statistically significantly different from each other. According to the results from Table 5, there were statistically significant differences in customer perception between age groups, occupation groups, income levels, and frequency of use. Therefore, hypotheses $\mathrm{H} 1 \mathrm{c}, \mathrm{H} 1 \mathrm{e}, \mathrm{H} 1 \mathrm{f}$, and $\mathrm{H} 1 \mathrm{~g}$ are accepted. It means that customer perception of e-banking is significantly different between age groups, occupations, income levels, and frequency of use. In another study of customer perception of e-banking in private and public banks in India, Fozia (2013) also found that there were statistically significant differences between age, occupation levels of customers and their perception of e-banking services. 
Table 6. Multiple comparisons of mean difference of age by Tukey technique

\begin{tabular}{llllll}
\hline & Less than 20 & $20-29$ & $30-39$ & $40-49$ & More than 49 \\
\hline Less than 20 & 1 & 0.07898 & & & \\
$20-29$ & & 1 & $-.12467^{*}$ & -.09127 & -.21470 \\
$30-39$ & & & 1 & .03340 & -.09003 \\
$40-49$ & & & & 1 & -.12343 \\
More than 49 & & & & 1 \\
\hline
\end{tabular}

*. The mean difference is significant at the 0.05 level.

A Tukey post hoc test revealed that customer perception of electronic banking of age group from 20 to 29 (Mean $=3.27 \pm 0.30548$ ) was statistically significantly lower than age group from 30 to 39 (Mean $=3.3957 \pm 0.33546$, $p=.022$ ). There was no statistically significant difference between other age groups.

Table 7. Multiple comparisons of mean difference of occupations by Tukey technique

\begin{tabular}{lrrrrrc}
\hline & Student & Government Employee & Company's employee & Housewife/husband & Self-employed & Others \\
\hline Student & 1 & -.08106 & .00002 & .13514 & -.11067 & -.13989 \\
Government Employee & & 1 & .08108 & $.21621^{*}$ & -.02960 & -.05883 \\
& & & & & & \\
Company's employee & & & 1 & .13512 & -.11069 & -.13991 \\
& & & & & $-.24581^{*}$ & $-.27503^{*}$ \\
Housewife/husband & & & & & 1 & -.02922 \\
Self-employed & & & & & 1 \\
Others & & & & & 1 \\
\hline
\end{tabular}

*. The mean difference is significant at the 0.05 level.

A Tukey post hoc test revealed that customer perception of electronic banking of government employee $($ Mean $=$ $3.3778 \pm 0.37284$ ) was statistically significantly higher than housewife/husband occupation (Mean $=3.1616 \pm$ $0.2218, p=.006$ ) while housewife/husband has lower customer perception of e-banking than self-employed $($ Mean $=3.4070 \pm 0.39697, p=.006)$ and others (Mean $=3.4367 \pm 0.3486, p=.001)$. There was no statistically significant difference between other occupation groups.

Table 8. Multiple comparisons of mean difference of income levels by Tukey technique

\begin{tabular}{|c|c|c|c|c|c|c|c|c|}
\hline & $\begin{array}{l}\text { Less than } 5 \text { mil } \\
\text { VND }\end{array}$ & 5 mil- 10 mil VND & $\begin{array}{l}10 \text { mil- } \\
\text { VND }\end{array}$ & 15 mil & $\begin{array}{l}15 \text { mil- } \\
\text { VND }\end{array}$ & 20 mil & $\begin{array}{l}20 \text { mil- } 25 \text { mil } \\
\text { VND }\end{array}$ & $\begin{array}{l}\text { More than } 25 \\
\text { mil VND }\end{array}$ \\
\hline $\begin{array}{l}\text { Less than } 5 \text { mil } \\
\text { VND }\end{array}$ & 1 & $-.19618^{*}$ & & $-.19425^{*}$ & & -.21373 & -.13462 & $-.35762^{*}$ \\
\hline 5 mil- 10 mil VND & & 1 & & .00193 & & -.01755 & .06156 & -.16144 \\
\hline 10 mil- 15 mil VND & & & & 1 & & -.01948 & .05963 & -.16337 \\
\hline 15 mil- 20 mil VND & & & & & & 1 & .07911 & -.14389 \\
\hline 20 mil- 25 mil VND & & & & & & & 1 & -.22300 \\
\hline $\begin{array}{l}\text { More than } 25 \text { mil } \\
\text { VND }\end{array}$ & & & & & & & & 1 \\
\hline
\end{tabular}

*. The mean difference is significant at the 0.05 level.

According to the results in Table A, Tukey post hoc test showed that customers who earned income "less than 5 million VND" had lower customer perception of e-banking than those customers with higher income "5-10 million VND" (Mean = 3.1974 $\pm 0.29545, p=0.000)$, “10 -15 million VND" $($ Mean $=3.3936 \pm 0.32778, p=$ 0.011 ), and "more than 25 million VND" (Mean $=3.555 \pm 0.45075, p=0.034)$. There was no statistically significant difference in customer perception among other income levels. 
Table 9. Multiple comparisons of mean difference of frequency of use by Tukey technique

\begin{tabular}{lllll}
\hline & Never & Once a month & Once a week & More than once a week \\
\hline Never & 1 & .00973 & -.11699 & $-.22882^{*}$ \\
Once a month & & 1 & $-.12672^{*}$ & $-.23855^{*}$ \\
Once a week & & & 1 & -.11183 \\
More than once a week & & & & 1 \\
\hline
\end{tabular}

The results in Table 9 indicated that there was a statistically significant difference between customers who "never" (Mean $=3.24 \pm 0.39517, p=0.048)$ used e-banking and those who used e-banking "more than once a week" (Mean $=3.4688 \pm 0.33515)$. The Tukey post hoc test also showed that customers who used e-banking "once a month" (Mean $=3.2303 \pm 0.31732)$ had statistically significant lower customer perception from those who used it "once a week" (Mean $=3.357 \pm 0.31586, p=0.018$ or "more than once a week" (Mean $=3.4688 \pm$ $0.33515, p=0.000)$.

\subsection{Pearson Correlation Analysis}

Table 10. Pearson correlation between customer perception of electronic banking and customer satisfaction

\begin{tabular}{lll}
\hline & & SatisfactionAverage \\
\hline \multirow{3}{*}{ CustomerPerception } & Pearson Correlation & $.504^{* *}$ \\
& Sig. (2-tailed) & .000 \\
& $\mathrm{~N}$ & 350 \\
\hline
\end{tabular}

**. Correlation is significant at the 0.01 level (2-tailed).

The findings from Table 10 reported a significant positive relationship between customer perception of electronic bank and customer satisfaction. This confirms that when customers have a positive perception about electronic banking, they will have more satisfaction with the electronic banking service.

Table 11. Pearson correlation between customer perception of different aspects and customer satisfaction

\begin{tabular}{|c|c|c|c|c|c|c|c|c|c|}
\hline & Convenience & Speed & Security & $\begin{array}{l}\text { Ease of } \\
\text { use }\end{array}$ & $\begin{array}{l}\text { Service } \\
\text { costs }\end{array}$ & Reliability & $\begin{array}{l}\text { Quality of } \\
\text { Service }\end{array}$ & Procedure & $\begin{array}{l}\text { Satisfaction } \\
\text { Average }\end{array}$ \\
\hline Convenience & 1 & $.450^{* *}$ & $.337^{* *}$ & $.441^{* *}$ & $.179^{* *}$ & $.392^{* *}$ & $.237^{* *}$ & $.448^{* *}$ & $.313^{* *}$ \\
\hline Speed & & 1 & $.292^{* *}$ & $.497^{* *}$ & $.178^{* *}$ & $.218^{* *}$ & $.363^{* *}$ & $.484^{* *}$ & $.514^{* *}$ \\
\hline Security & & & 1 & $.255^{* *}$ & $.137^{*}$ & $.497^{* *}$ & .021 & $.244^{* *}$ & $.253^{* *}$ \\
\hline Ease of use & & & & 1 & $.191^{* *}$ & $.347^{* *}$ & $.307^{* *}$ & $.520^{* *}$ & $.451^{* *}$ \\
\hline Service costs & & & & & 1 & $.108^{*}$ & $.184^{* *}$ & $.312^{* *}$ & .103 \\
\hline Reliability & & & & & & 1 & .012 & $.117^{*}$ & $.268^{* *}$ \\
\hline $\begin{array}{l}\text { Quality of } \\
\text { Service }\end{array}$ & & & & & & & 1 & $.344^{* *}$ & $.245^{* *}$ \\
\hline Procedure & & & & & & & & 1 & $.312^{* *}$ \\
\hline $\begin{array}{l}\text { Satisfaction } \\
\text { Average }\end{array}$ & & & & & & & & & 1 \\
\hline
\end{tabular}

**. Correlation is significant at the 0.01 level (2-tailed).

*. Correlation is significant at the 0.05 level (2-tailed).

To understand which areas of customer perception of electronic banking are related to customer satisfaction, the researchers used Pearson's correlation and found that customer perception of convenience, speed, security, ease of use, reliability, quality of service, and procedure had a significant positive relationship with customer satisfaction. In addition, the results also indicated that service costs are not significantly related to customer satisfaction. Similar research about customer perception of online banking service quality and its relationship with customer satisfaction and loyalty in South Africa provided a similar result that factors such as assurance, responsiveness, ease of use, accessibility, fulfillment, speed and accuracy, and contact affect customer satisfaction and loyalty (Dhurup, Surujlal, \& Redda, 2014). 


\subsection{Reliability}

Table 12. Reliability Statistics

\begin{tabular}{ll}
\hline Cronbach's Alpha & N of Items \\
\hline .808 & 38 \\
\hline
\end{tabular}

The reliability statistics illustrated that Cronbach's Alpha is 0.808 which is greater than 0.7 . This pointed that the research questions were reliable.

\section{Discussions}

The results from this study have shown what customers perceived about the current e-Banking service in Vietnam. Most customers felt that electronic banking was convenient, there are many types of electronic banking services for them to use and they can access them anywhere. The majority of customers also agreed that the speed of ATM, mobile, and internet banking was fast. Almost half of the customers felt that it was secured to pay money through electronic banking and most of customers also believed that their private information was protected when using online transactions. However, a large number of customers were afraid to withdraw money at the ATM booth. It could be understood as there were many robbery cases at ATM both when customers were using the service in less crowding areas.

In addition, many customers had no opinion about the procedure and length of time for applying for electronic banking services. Though some expressed that the procedure of completing a transaction of e-banking was simple, some customers felt that the procedure dealing with complaints was complicated. Most of the customers indicated that electronic banking was easy to use, the website had a friendly design, and there were instruction manuals available for them. While some customers showed that the annual fee of banking cards and service fee of electronic banking was high, others said that the transaction fee with electronic banking was still lower than conventional banking. Moreover, the majority of customers were confident that transactions of e-banking and records of them were reliable. They also believed that the quality of internet and mobile banking was good and convenient. However, most of them were unsure if the banks would reimburse the money to them when personal information was lost due to the security faults of the banks. Customers also expressed that there were still some problems with the ATM service.

From this study, researchers also found that gender, marital status, education levels had no significant influence on the customer perceptions of electronic banking in Vietnam. However, there were differences in customers' perceptions among ages, occupations, income levels, and frequency of using electronic banking. These findings implied that bank managers should select the most effective marketing strategies for different groups of ages, occupations, income levels and frequency of use so that they can enhance the perception of customers about electronic banking. Bank managers may design appropriate promotion programs or campaigns that can attract customers to use electronic banking services and also increase the awareness of customers about electronic banking.

In addition, the study also confirms that convenience, speed, security, ease of use, reliability, quality of service, and procedure were positively related to customer satisfaction. The results also confirm with the study of Dhurup, Surujlal, \& Redda (2014). In a similar study of customer perception of electronic banking in Pakistan, it was also found that reliability, convenience, speed, safety, and security were the main factors that affect customer satisfaction (Omar, et al., 2011). This helps bank managers to prioritize improving their current services in these areas to increase the satisfaction of customers. Moreover, the research also found that there is no relationship between service costs and customer satisfaction. This information is useful for managers in making decisions about adjusting electronic bank service costs.

There were some limitations in doing this research. Firstly, the sample, which included three hundred and fifty customers, was small, when compared to the total number of customers in the region. This limitation was due to budget constraints. Secondly, this study was conducted in Vietnam, and, it may not reflect the perceptions of customers outside this region.

The researchers recommend that further studies should expand the sample size. This could be done by involving customers from other Asian countries for comparison purposes among different cultures. A study on the impacts of each electronic banking type such as ATM, mobile, and internet banking on customer satisfaction may be done to gain perspective about the effectiveness of electronic banking services. 


\section{References}

Al-Hawari, M., Harley, N., \& Ward, T. (2005). Measuring banks' Automated Service Quality, A Confirmatory Factor Analysis Approach. Marketing Bulletin, 16, 1-19.

Appota. (2018). Vietnam Mobile App Market Report - First half of 2018. Ha Noi: Appota. Retrieved July 15, 2019, from https://appota.com/uploads/report/Vietnam_mobile_app_market_Report_2018_EN.pdf

Black, N. J., Lockett, A., Winklhofer, H., \& Ennew, C. (2001). The Adoption of Internet Financial Services: A Qualitative Study. International Journal of Retail and Distribution Management, 29(8), 390-398. https://doi.org/10.1108/09590550110397033

Burke, R. R. (2002). Technology and the Customer Interface: What Consumers Want in the Physical and Virtual Store. Journal of the Academy of Marketing Science, 30(4), 411-432. https://doi.org/10.1177/009207002236914

Cooper, R. G. (1997). Examining Some Myths about New Product Winners. In Katz, R. (Ed.), The Human Side of Managing Technological Innovation (pp. 550-600). Oxford University Press.

Dhurup, M., Surujlal, J., \& Redda, E. (2014). Customer Perceptions of Online Banking Service Quality and Its Relationship With Customer Satisfaction and Loyalty. Mediterranean Journal of Social Sciences, 5(8), 72-80. http://dx.doi.org/10.5901/mjss.2014.v5n8p72

Doan, E. Z. (2019, July 15). Vietnam: number of internet users 2017-2023. Retrieved from https://www.statista.com/statistics/369732/internet-users-vietnam/

Fonchamyo, D. C. (2013). Customer Perception of E-Banking Adoption in Cameroon: An Empirical Assesment of an Extended TAM. International Journal of Economics and Finance, 5(1), 166-176. http://dx.doi.org/10.5539/ijef.v5n1p166

Fozia. (2013). A Comparative Study of Customer Perception toward E-banking Services Provided By Selected Private \& Public Sector Bank in India. International Journal of Scientific and Research Publications, 3(9), 1-5.

Gbadeyan, R. A., \& Akinyosoye-Gbonda, O. (2011). Customer' Preference for E - Banking Services: A Case Study of Selected Banks in Sierra Leone. Australian Journal of Business and Management Research, 1(4), 108-116.

Gonzalez, M. E., Mueller, R. D., \& Mack, R. W. (2008). An Alternative Approach in Service Quality: An E-Banking Case Study. Quality Management Journal, 15(1), 41-58. https://doi.org/10.1080/10686967.2008.11918055

Hassan, M. T. (2012). Customer Service Quality Perception of Internet Banking. Internationl Journal of Learning \& Development, 2(2), 86-100. https://doi.org/10.5296/ijld.v2i2.1591

Hernandez-Orteg, B., Jimenez-Martinez, J., \& Hoyos, J. (2007). An Analysis of Web Navigability in Spanish Internet Banking. Journal of Internet Banking and Commerce, 12(3), 1-8.

Mansor, N., Shariff, A., \& Manap, N. (2012). Determinants of Awareness on Islamic Financial Institution E-Banking among Malaysian SMEs. International Journal of Business and Social Science, 3(5), 93-101.

Nielson Company. (2010). Personal Finance Monitor. Retrieved from http://www.nielsen.com/intl/vn/news-insights/reports/3g-and-young-generation/personal-finance-monitor.ht $\mathrm{ml}$

Omar, A. B., Sultan, N., Zaman, K., Bibi, N., Wajid, A., \& Khan, K. (2011). Customer Perception towards Online Banking Services: Empirical Evidence from Pakistan. Journal of Internet Banking and Commerce, 16(2), 1-24.

Santos, J. (2003). E-Service Quality: A Model of Virtual Service Quality Dimension. Managing Service Quality, 13(3), 233-246. https://doi.org/10.1108/09604520310476490

Singhal, D., \& Padhmanabhanm, V. (2008). A Study on Consumer Perception Towards Internet Banking: Idenntifying Major Contributing Factors. The Journal of Nepalase Business Studies, 5(1), 101-111. https://doi.org/10.3126/jnbs.v5i1.2088

Srivastava, K. S. (2007). Customer's Perception on Usage of Internet Banking. Innovative Marketing, 3(4), 67-73. 
Williamson, G. D. (2006). Enhanced Authentication In Online Banking. Journal of Economic Crime Management, 4(2), 1-42.

\section{Copyrights}

Copyright for this article is retained by the author(s), with first publication rights granted to the journal.

This is an open-access article distributed under the terms and conditions of the Creative Commons Attribution license (http://creativecommons.org/licenses/by/4.0/). 